Institute for Research on Poverty

Discussion Paper no. 1020-93

\title{
The Earned Income Tax Credit: Participation, Compliance, and Antipoverty Effectiveness
}

\author{
John Karl Scholz \\ Department of Economics \\ La Follette Institute of Public Affairs \\ Institute for Research on Poverty \\ University of Wisconsin-Madison
}

September 1993

I have benefited from detailed conversations with John Coder at the Census Bureau and George Yin at the University of Florida, and am fortunate and grateful that both were willing to share their expertise and support. Thanks also to Stacy Dickert, Elizabeth Evanson, William Gale, Janet Holtzblatt, Mark Mazur, Andrew Samwick, and Daniel Weinberg. This work was supported by a grant from the U.S. Department of Health and Human Services to the Institute for Research on Poverty. Any views expressed here are those of the author alone. 


\begin{abstract}
This paper examines the participation rate of the earned income tax credit (EITC). After examining a variety of data sources on EITC recipiency, my preferred estimates indicate that 80 to 86 percent of eligible taxpayers received the credit in 1990, which implies fewer than 2.1 million taxpayers entitled to the credit failed to receive it. I then examine factors correlated with nonparticipation and find that many are consistent with rational or voluntary explanations for nonparticipation. The paper concludes with a discussion of the labor market incentives and antipoverty effectiveness of the credit before and after the August 1993 expansion of the EITC.
\end{abstract}




\section{The Earned Income Tax Credit: Participation, Compliance, and Antipoverty Effectiveness}

In his first State of the Union address, President Clinton announced: "The new direction I propose will make this solemn, simple commitment: by expanding the refundable earned income tax credit, we will make history; we will reward the work of millions of working poor Americans by realizing the principle that if you work 40 hours a week and you've got a child in the house, you will no longer be in poverty" (Shapiro and Greenstein, 1993). To meet this goal the president included in his budget a substantial increase in the earned income tax credit (EITC), which is directed at low-income families with children.

In 1990, the year of my data, the EITC equaled 14 percent of earned income (wages, salaries, self-employment income, and farm income), provided that the amount of earned income did not exceed $\$ 6,810$; hence, the maximum benefit was $\$ 953$ (14 percent of $\$ 6,810$ ). This initial stage of the EITC benefit schedule is referred to as the subsidy range of the credit. Because benefits increase with earned income (up to a certain point), the EITC seems to encourage work and therefore is a popular antipoverty program. Taxpayers whose incomes exceeded $\$ 6,810$ but were less than $\$ 10,730$ received exactly the maximum benefit; this income interval is known as the flat range of the credit. Taxpayers whose incomes exceeded $\$ 10,730$ were in the phase-out range of the credit: their $\$ 953$ credit was reduced by 10 cents for every dollar of income earned over and above $\$ 10,730$. Unlike most credits and deductions in the federal individual income tax system, the EITC is refundable--that is, if the amount of the credit exceeds what the taxpayer owes, he or she receives a payment from the U.S. Treasury for the difference.

The EITC was adopted in 1975 and was originally promoted as a way to relieve the burden of the social security payroll tax on low-wage working parents. The original EITC equaled 10 percent of earnings up to a maximum credit of $\$ 400$ for taxpayers with children, and was phased out at a rate of 10 cents per dollar of earnings (or adjusted gross income, whichever was higher) for incomes between 
$\$ 4,000$ and $\$ 8,000$. By the time President Clinton's EITC proposals, now enacted, are fully phased in, the credit rate will be 40 percent of earnings for families with two or more children, and 34 percent for families with one child, and will for the first time provide a 7.65 percent credit to childless taxpayers with low incomes. The maximum credit (in 1994 dollars) for taxpayers with two or more children will be $\$ 3,370$; for taxpayers with one child, $\$ 2,040$; and for taxpayers with no children, \$306. The credit will be the largest cash or near-cash program directed at low-income households. This paper first examines the participation (or take-up) rate--defined as the percentage of the eligible population that receives the credit--of the EITC. ${ }^{1}$ Given the central role the EITC plays in public policy as it affects the working poor, it is important to assess whether the intended beneficiaries receive the credit. Because the credit is operated through the tax system, increasing the EITC to assist the working poor will be ineffective if taxpayers do not file tax returns. The participation rate will also influence cost estimates of EITC expansion.

It is difficult to estimate EITC participation rates. Household surveys generally collect the information needed to determine eligibility, but do not provide information on EITC recipiency. Tax data are best for estimating EITC recipiency, but not all households file tax returns and tax data do not provide demographic characteristics, so they are unsuited for estimating EITC eligibility. In the only previous analysis of EITC participation (Scholz, 1990), I pieced together disparate sources of EITC data and estimated that the EITC participation rate was 70 percent in 1984, which means that roughly 1.65 million eligible taxpayers failed to receive the credit because they did not file tax returns. The

\footnotetext{
${ }^{1}$ The EITC has been mentioned or analyzed in many other studies. Danziger, Haveman, and Plotnick (1986), Wilson (1987), Ellwood (1988), Haveman (1988), and Forman (1989), among others, have proposed EITC increases as part of larger reforms of the income transfer system. Steuerle and Wilson (1986, 1987) present a general description and analysis of the EITC; Gabe (1989) presents a static incidence analysis of several proposals to alter the EITC; Hoffman and Seidman (1990) discuss the antipoverty effectiveness of the credit and simulate labor supply effects; U.S. General Accounting Office (1992a) examines the use of the prepayment option of the EITC; Yin and Forman (1993) examine design and compliance issues associated with the credit; and Gabe (1993) presents a detailed description of the characteristics of EITC-eligible households.
} 
EITC, however, has changed significantly since 1984. In addition, data are now available that allow EITC eligibility and EITC recipiency to be determined in the same data set: specifically, the 1990 Survey of Income and Program Participation (SIPP) was matched by social security number to selected items from individual income tax returns. ${ }^{2}$ Given the changes in the credit and the unique data available to address the issue, I provide new estimates of EITC participation in 1990.

To calculate participation rates, I first determine the number of taxpayers eligible for the EITC by simulating the 1990 EITC statutes for each respondent in the sample. I then determine the number of recipients out of the population of eligibles. Data on EITC recipiency come from three sources: the Green Book (U.S. House of Representatives, 1993), tax returns filed by households, and the SIPP tax topical module. The Green Book (p. 1058) reports the number of taxpayers receiving the EITC based on data from the Internal Revenue Service (IRS). However, data from the IRS Taxpayer Compliance Measurement Program (TCMP) indicate that over 3.4 million taxpayers inappropriately claimed the EITC in $1988 .^{3}$ Estimates from the Green Book of the number of taxpayers that receive the credit must therefore be adjusted for receipt by ineligibles. I make these calculations and adjustments below. The second source of recipiency data is the number of taxpayers who filed tax returns entitling them to the credit. Information from the matched tax returns combined with data from SIPP allow me to precisely calculate the number of EITC-eligible taxpayers who filed returns. Through 1990, taxpayers who filed returns with the IRS and failed to claim the EITC but were eligible had their returns adjusted by the IRS so that the correct payment or refund was made. Knowing that

\footnotetext{
${ }^{2}$ See Jabine (1990) for details about the SIPP. Tax return items were matched to the 1990 SIPP through an arrangement between the Census Bureau and the Internal Revenue Service. Since the data resulting from the SIPP-IRS match are not available for public use, all work relating to the matched data was carried out at the Census Bureau by staff having authorized access to the linked data sets. The matched tax returns unfortunately do not include whether or not the taxpayer filed for the EITC, self-employment income, and exemptions for children away from home.

${ }^{3}$ A General Accounting Office official recently testified that "the credit has been the source of more taxpayer mistakes than any other individual income tax provision" (Stathis, 1993).
} 
an eligible taxpayer filed a return, therefore, lets me know that he or she received the credit, even though I am missing the EITC information from the matched tax returns. The third source of recipiency data is a tax topical module that SIPP gathers to supplement its core data on program participation, incomes, and demographics. In this module households are asked directly about EITC participation; response rates, however, are quite low.

While each of the data sources on EITC recipiency has limitations, they allow me to take three different approaches to calculating participation. I get a range of estimates, but the best evidence suggests that the participation rate in 1990 was 80 to 86 percent, which indicates fewer than 2.1 million eligible taxpayers failed to receive the credit.

In Section II I examine the characteristics of eligible claimants, eligible households that fail to file, and ineligible households that claim the EITC. Previous analyses have been unable to provide such information because without the matched tax return data, analysts have been unable to determine both who is eligible and who received the credit using a single data set. Examining the characteristics of eligible households that fail to file for the credit should aid outreach efforts to increase participation and provide insight into the reasons for which households fail to participate. ${ }^{4}$ In addition, I provide evidence on the characteristics of ineligible households that nevertheless claim the credit, though data limitations cause the results of this analysis to be more speculative than the other results in the paper.

In Section III I simulate the antipoverty effectiveness of the EITC prior to and after the August 1993 budget legislation (the Omnibus Budget Reconciliation Act of 1993, OBRA93) that expanded the EITC. The simulations focus on two issues: the number of working-poor families whose incomes are raised above the poverty line by the EITC, and the fraction of total EITC benefits that go to families with incomes below the poverty line. The simulations also show the number of families whose

\footnotetext{
${ }^{4}$ Outreach efforts include those conducted by the Center for Budget and Policy Priorities (Wall Street Journal, 7/13/89, p.A16), the Greater Milwaukee Committee (1990), Congress for Working America (1992), and the Internal Revenue Service (Lullo, 1993).
} 
incomes are in the subsidy range, the flat range, and the phase-out range of the credit. As Hoffman and Seidman (1990) and Kosters (1993) discuss, the work incentives of the credit vary significantly among these groups, and data on the number of families that fall into each range are difficult to gather from published sources.

\section{THE PARTICIPATION RATE OF THE EITC}

The first subsection describes how I identify households eligible for the EITC. The remaining subsections describe three different approaches to determining the number of eligible taxpayers that receive the credit. The first approach pieces together disparate sources of information, the second exploits the exact match file and the knowledge that eligible filers receive the credit, and the third uses the tax topical module questions. For reasons discussed below, the second measure provides the preferred estimate.

\section{a) Eligible Population}

I use data from the 1990 SIPP covering calendar year 1990 to determine the number of taxpayers eligible for the EITC. The 1990 SIPP is a random stratified sample of 22,994 households that, when weighted, represent the civilian noninstitutionalized U.S. population. Each of four staggered rotation groups are interviewed every four months about monthly labor market behavior, income sources, and household composition. The 1990 calendar year file aggregates 1990 household information from January 1 to December 31, fixing family composition as of January 1, 1991. The family and individual SIPP data provide most of the information needed to simulate the income tax returns these family units could have or did file. 
The major factors determining EITC eligibility in 1990 were: (1) supporting a child, ${ }^{5}$ (2) having earned income between $\$ 1$ and $\$ 20,264,{ }^{6}$ and (3) having less than $\$ 20,264$ of adjusted gross income. Table 1 presents details on EITC program parameters for the different years discussed in the paper. Because of the complexity of the rules governing the EITC and the limitations of the underlying SIPP data, I make several simplifications in determining the population of EITC-eligible taxpayers.

I treat all subfamilies, primary individuals, and secondary individuals as potentially separate (from the primary family) tax-filing units. Ignoring momentarily the support test (see note 5), I treat a household as having a qualified child as long as the tax-filing unit has a child under the age of 18 or has a child between the ages of 18 and 24 who is a full-time student, where full-time student status is proxied by having some college education and working full time for less than half the year. Thus in my calculations, I exclude two types of families who otherwise qualify for the EITC: low-income families whose youngest child is disabled and older than 17, and low-income families whose youngest

\footnotetext{
${ }^{5}$ Rules governing whether or not a taxpayer supports a child are complicated. Holtzblatt (1991, p. 191) states (for rules in effect in 1990): "Single parents had to demonstrate that they provided over half the costs of maintaining a household in which a child resided, while married couples had to show that they provided over half the costs of a supported child. Further, the definition of a qualifying child differs among families on the basis of marital status." AFDC and child support receipts, for example, are considered support that is not provided by the taxpayer, and hence may make the taxpayer ineligible for the credit. In OBRA90 the rules were simplified so that a qualifying child became any disabled child or any offspring under the age of 19 (or under 24 if the child is a full-time student) who lives in the home for more than half the year.

${ }^{6}$ For the purposes of the EITC, earned income includes not only wage, salary, farm, and selfemployment income, but sources such as housing allowances or the rental value of a parsonage for the clergy, excludable employer-provided dependent care benefits, nontaxable military quarters and subsistence benefits, voluntary salary reduction amounts (e.g., deductions to 401(k) plans), and anything else of value (money, goods, or services) received from someone for services performed even if it is not taxable (IRS Publication 596).
} 
TABLE 1

EITC Parameters under Law Prior to OBRA93 and under OBRA93, Selected Years (figures for 1994 and beyond are in 1994 dollars)

\begin{tabular}{|c|c|c|c|c|c|c|}
\hline & \multirow[b]{2}{*}{ Credit Rate } & \multicolumn{2}{|c|}{ Flat Range } & \multirow[b]{2}{*}{ Max. Credit } & \multicolumn{2}{|c|}{ Phase-out Range } \\
\hline & & Beginning Income & Ending Income & & Phase-out Rate & Income Cuto \\
\hline \multicolumn{7}{|l|}{ Prior Law } \\
\hline \multicolumn{7}{|l|}{$1990(1990$ \$) } \\
\hline All taxpayers & $14 \%$ & $\$ 6,810$ & $\$ 10,730$ & $\$ 953$ & $10 \%$ & $\$ 20,264$ \\
\hline \multicolumn{7}{|l|}{1993 (1993 \$) } \\
\hline 1 qualified child & 18.5 & 7,750 & 12,200 & 1,434 & 13.21 & 23,050 \\
\hline $2+$ qualified children & 19.5 & 7,750 & 12,200 & 1,511 & 13.93 & 23,050 \\
\hline Young child ${ }^{a}$ & 5 & 7,750 & 12,200 & 388 & 3.57 & 23,050 \\
\hline Health credit ${ }^{\mathrm{b}}$ & 6 & 7,750 & 12,200 & 465 & 4.285 & 23,050 \\
\hline \multicolumn{7}{|l|}{1994 and after } \\
\hline 1 qualified child & 23 & 7,990 & 12,680 & 1,838 & 16.43 & 23,760 \\
\hline $2+$ qualified children & 25 & 7,990 & 12,680 & 1,998 & 17.86 & 23,760 \\
\hline Young child ${ }^{a}$ & 5 & 7,990 & 12,680 & 400 & 3.67 & 23,760 \\
\hline Health credit ${ }^{\mathrm{b}}$ & 6 & 7,990 & 12,680 & 479 & 4.285 & 23,760 \\
\hline \multicolumn{7}{|c|}{ Omnibus Budget Reconciliation Act of 1993 (OBRA93) } \\
\hline \multicolumn{7}{|l|}{1994} \\
\hline 1 child & 26.3 & 7,750 & 11,000 & 2,038 & 15.98 & 23,760 \\
\hline $2+$ children & 30.0 & 8,425 & 11,000 & 2,528 & 17.68 & 25,300 \\
\hline No qualifying child ${ }^{c}$ & 7.65 & 4,000 & 5,000 & 306 & 7.65 & 9,000 \\
\hline
\end{tabular}

(table continues) 
TABLE 1, continued

\begin{tabular}{|c|c|c|c|c|c|c|}
\hline & \multirow[b]{2}{*}{ Credit Rate } & \multicolumn{2}{|c|}{ Flat Range } & \multirow[b]{2}{*}{ Max. Credit } & \multicolumn{2}{|c|}{ Phase-out Range } \\
\hline & & Beginning Income & Ending Income & & Phase-out Rate & Income Cutoff \\
\hline \multicolumn{7}{|l|}{1995} \\
\hline 1 child & 34.0 & 6,000 & 11,000 & 2,040 & 15.98 & 23,760 \\
\hline $2+$ children & 36.0 & 8,425 & 11,000 & 3,033 & 20.22 & 26,000 \\
\hline No qualifying child ${ }^{c}$ & 7.65 & 4,000 & 5,000 & 306 & 7.65 & 9,000 \\
\hline \multicolumn{7}{|l|}{1996 and beyond } \\
\hline 1 child & 34.0 & 6,000 & 11,000 & 2,040 & 15.98 & 23,760 \\
\hline $2+$ children & 40.0 & 8,425 & 11,000 & 3,370 & 21.06 & 27,000 \\
\hline No qualifying child ${ }^{\mathrm{c}}$ & 7.65 & 4,000 & 5,000 & 306 & 7.65 & 9,000 \\
\hline
\end{tabular}

Source: Figures for the August 1993 budget agreement (OBRA93) were kindly provided by Janet Holtzblatt at the Office of Tax Analysis, U.S. Department of Treasury. The other figures are from U.S. House of Representatives (1993).

${ }^{a}$ The young child (or "wee tots") credit was for taxpayers who had a child under the age of one in the tax year and incomes in the ranges designated in the table.

${ }^{\mathrm{b}}$ The supplemental health insurance credit goes to taxpayers with incomes in the range designated in the table who paid health insurance premiums that include coverage for one or more qualifying children. The taxpayer cannot take advantage of the supplemental health insurance credit on expenses used for the medical expense deduction or health insurance deduction for the self-employed (and vice versa).

${ }^{\mathrm{c}}$ The taxpayer must be between the ages of 25 and 65 . 
child is 18 years old and not a full-time student. The support test is modeled by comparing total labor and capital income to the sum of AFDC and child support. ${ }^{7}$ If AFDC and child support exceed labor and capital income, I assume the taxpayer fails the support test. The main weakness of this proxy for the support test is that in practice the imputed rental value of housing counts as support, so a homeowning parent with little labor and capital income that receives child support would inappropriately fail my proxy support test. For the same reason, a poor household receiving public housing would be unlikely to pass the test in practice, but could pass my proxy. As shown below, the support test does not make a large difference in the EITC eligibility simulations.

Earned income is computed by adding wage and salary, self-employment, and farm income of both the head and the spouse (if present), but ignoring the income from children and other family members. This definition captures the most important sources of earned income, but misses the additional items listed in IRS Publication 596 (see note 6) because I do not have the requisite data. ${ }^{8}$ Adjusted gross income (AGI) is computed by adding to earned income the head of household's and spouse's interest, dividends, rents, royalties, net capital gains, taxable social security benefits (50 percent of social security payments to single taxpayers with incomes exceeding $\$ 25,000$ or $\$ 32,000$ for married couples), 75 percent of pension and retirement income, ${ }^{9}$ alimony, and unemployment

\footnotetext{
${ }^{7}$ Labor and capital income is the sum of wages and salaries, farm income, self-employment income, interest, dividends, social security, and realized capital gains. AFDC includes general assistance.

${ }^{8}$ IRS Publication 596 gives details on EITC rules. Even if the additional data were available, most of the omitted items are quantitatively small. Those that are not, such as money, goods, or services provided as compensation for services performed, may be extremely difficult to verify, even by an audit.

${ }^{9}$ The U.S. Bureau of the Census (1992, tables 579 and 563) reports that $\$ 82$ billion in government pensions and $\$ 129.7$ in private pensions were paid in 1989. The U.S. Internal Revenue Service (1992b) reports that taxable pension and annuity income was $\$ 147.4$ billion in 1989 , which suggests as a rough calculation that 70 percent of pension and annuity income was taxable in 1989. Doing a similar calculation for earlier years suggests the percentage is growing over time; hence 75 percent was used in the calculations. Of course, EITC-eligible taxpayers receive relatively little pension and retirement income, so altering the 75 percent figure has little effect on the calculations.
} 
insurance. This definition of AGI differs primarily from that found on tax returns by excluding trust income and all adjustments to AGI (such as reimbursed employee business expenses and IRA and Keogh contributions) because either the information is not available in SIPP or response rates on the relevant questions are low.

Using only data from SIPP, I find that 9.7 million taxpayers were eligible for the EITC in 1990 when my proxy for the support test is imposed. When the support test is removed, so that a taxpayer "qualifies" for the credit simply by meeting the earned income and AGI criteria and having a child, the number of eligible households increases to 10.3 million. These results are consistent with those of Gabe (1993), who uses CPS data and finds that 10.7 million taxpayers were eligible for the credit in 1991. The Green Book (U.S. House of Representatives, 1993, p. 1058) shows that the number of taxpayers filing for the credit was projected to increase by 8.7 percent from 1990 to 1991 (presumably due to the weak economy). Applying this rate of increase to my 1990 figures indicates that 10.5 to 11.2 million would have been eligible in 1991 , which brackets Gabe's estimate. ${ }^{10}$

Constructing AGI from household survey data is difficult. For example, considerably more self-employment income is reported in the SIPP and the National Income and Product Accounts than is reported to the IRS. ${ }^{11}$ Inconsistent definitions of self-employment income could bias SIPP-based estimates of earned income and AGI. At the same time, Vaughan (1989) and the National Research Council (1993, p. 55) explain that the amount of income other than self-employment, wage, and salary income reported in the SIPP (and the CPS) is generally lower than that obtained by independent

\footnotetext{
${ }^{10}$ Scholz (1990) found that the 1984 SIPP yielded somewhat higher eligibility numbers than the 1984 CPS.

${ }^{11}$ Farm and self-employment income is $\$ 291.6$ billion in the 1990 SIPP, and proprietors' income with the inventory valuation adjustment and capital consumption allowance is $\$ 379.3$ billion in the National Income and Product Accounts in 1990 (U.S. Department of Commerce, 1991), while the sum of net business and professional income, net partnership and subchapter S corporation income, and net farm income reported on tax returns was $\$ 195.7$ billion in 1989 (U.S. Internal Revenue Service, 1992a).
} 
estimates. Any analysis using the SIPP (or CPS) that attempts to model tax returns faces these problems (see, for example, Scholz, 1990, and Gabe, 1993). However, the Census Bureau cooperated in providing special tabulations based on publicly restricted files containing tax return data matched with SIPP data, which allows me to use tax return information when available to calculate an additional definition of eligibility. In particular, for households for which an exact match was made, AGI, earnings, filing status, and the child-at-home exemption were used to determine eligibility. The support test is incorporated in the filing status designation. Under this definition an EITC-eligible taxpayer must (i) file as head of household, surviving spouse, or married couple filing jointly, (ii) take a child-at-home exemption, (iii) have AGI less than $\$ 20,264$, and (iv) have wage and salary income between $\$ 1$ and $\$ 20,264 .{ }^{12}$

For 68.8 percent of the households a validated social security number was given and the household was matched to the tax return(s) it filed. ${ }^{13}$ For households not matched, SIPP core data were used to define EITC eligibility. This tax-return-based definition yields an estimate of the EITCeligible population of 10.1 million, which is roughly the midpoint of the estimates generated exclusively from SIPP data.

\footnotetext{
${ }^{12}$ This eligibility definition differs from the statute by excluding self-employment income from the definition of earned income and ignoring the child-away-from-home exemption in determining the presence of a child, because neither item was included on the matched tax returns. The bias from these omissions is likely to be small. AGI, which includes self-employment income, is used to determine eligibility. Moreover, in 1989 combined net business and professional, partnership and subchapter S, and farm income was 5.1 percent of total wage and salary income for all taxpayers with AGI between $\$ 1$ and $\$ 20,000$. Of the total exemptions claimed for children in 1989, 2.0 percent were taken for children away from home.

${ }^{13}$ Social security numbers provided by survey respondents who were in the first wave of SIPP were validated against Social Security records by name, age, sex, and birth date to ensure their accuracy.
} 


\section{b) Eligible Recipients}

The Green Book (U.S. House of Representatives, 1993, p. 1058) reports that 12.612 million taxpayers filed tax returns claiming the EITC in 1990. Dividing the number of EITC recipients by the number of eligible households leads to a participation rate of 122 to 130 percent. These figures obviously cannot measure the percentage of eligible households receiving the credit. They exceed 100 percent because a large number of ineligible taxpayers claimed the EITC; therefore, EITC recipiency data must be adjusted to exclude taxpayers receiving the credit who are technically ineligible. ${ }^{14}$ To do this I use unpublished data from the IRS's Taxpayer Compliance Measurement Program (TCMP). ${ }^{15}$

Summary TCMP data concerning the EITC, presented in Table 2, document the high rates of noncompliance associated with the credit. In 1982, 27 percent of all taxpayers who took the EITC were ineligible. The net dollar amount of inappropriately claimed credits was $\$ 513$ million out of total credit payments of $\$ 1,749$ million. In 1985 noncompliance was even more severe. Thirty-eight percent of all taxpayers who took the EITC were ineligible; $\$ 766$ million of $\$ 2,091$ million total was claimed inappropriately.

Legislative changes in the mid-1980s both encouraged and discouraged the filing of erroneous EITC claims. The first set of changes increased the credit to 14 percent in 1987 from 10 percent in 1984 , and raised the income eligibility cap from $\$ 10,000$ (in 1984) to $\$ 15,432$ (in 1987). Increasing the value of the credit increases the financial benefit to filing a false claim; at the same time,

\footnotetext{
${ }^{14}$ Scholz (1990) finds a similar result using SIPP and CPS data from 1984 and, after systematically exploring possible explanations, finds that problems with imputations and inadequate sample coverage in the SIPP and CPS cannot explain the result.

${ }^{15}$ The TCMP collects a stratified random sample of 50,000 tax returns every three years. Each selected taxpayer undergoes an intensive, comprehensive audit by a specially trained examiner. The audits focus on all items of the tax return. For more details about the TCMP program see Roth, Scholz, and Witte (1989, particularly pp. 65-69).
} 
TABLE 2

Taxpayer Compliance Measurement Program: Data on the Earned Income Tax Credit, 1982, 1985, and 1988

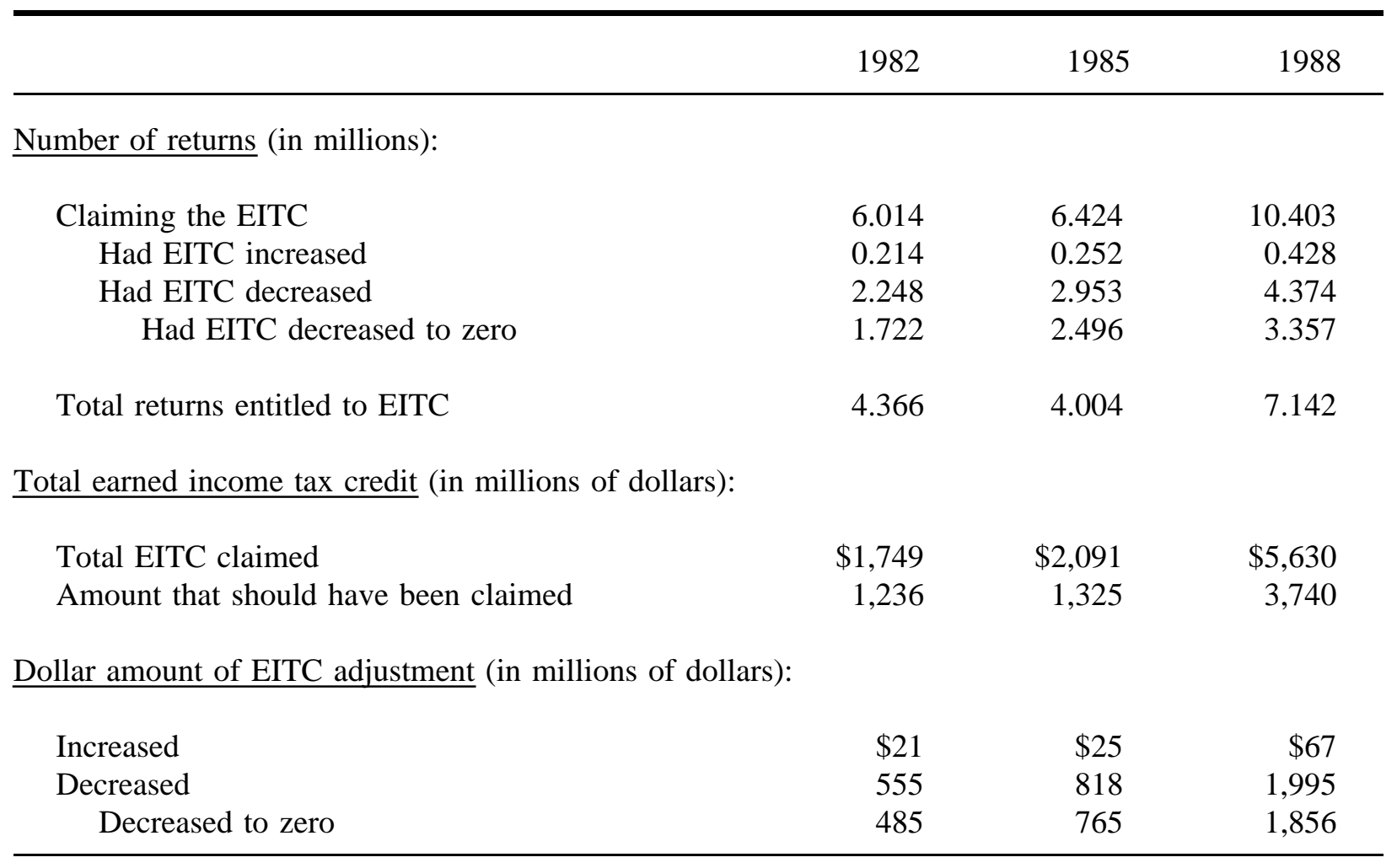

Source: Data are from unpublished worksheets of the Internal Revenue Service, Taxpayer Compliance Measurement Program, 1982, 1985, and 1988. The 1982 figures are from TCMP, Phase III, Cycle 8, 2/27/86. The 1985 figures are from TCMP, Phase III, Cycle 9, 4/11/89. The 1988 figures are from TCMP, Phase III, Cycle 10, 4/1/93.

Note: An additional category is excluded from the table: taxpayers who made a mistake elsewhere in their returns and thus were entitled to the EITC but failed to claim the credit. This category, which contains a small number of taxpayers, is labeled "not reported but established." This omitted category accounts for the slight difference between the second and third panels of the table. 
households with incomes between $\$ 10,000$ and $\$ 15,432$ might be expected to make fewer filing mistakes owing to greater familiarity with the tax system than those with lower incomes. The second set of changes required taxpayers to provide social security numbers for dependents over the age of five (the age threshold has since been lowered to one). In 1987 seven million fewer dependents than expected were claimed (see, for example, Forbes, 2/19/90 p. 74). ${ }^{16}$ Requiring social security numbers presumably made it more difficult for taxpayers to falsely claim dependents to qualify for the EITC.

The net effect of these changes on compliance was small. As shown in Table 2, in 198810.4 million taxpayers claimed the EITC while the TCMP for that year estimates that only 7.1 million were entitled to the credit, indicating that over 30 percent of EITC claimants were ineligible. Of the $\$ 5.6$ billion in EITC claims, the 1988 TCMP estimates that nearly $\$ 2$ billion (33.6 percent) were claimed inappropriately. Holtzblatt (1991, p. 184) provides information from the 1985 TCMP concerning reasons for disallowance of the EITC. Over half the returns were disqualified because the child exemption was disallowed, and over half the disqualified claimants had the filing status changed from one that entitled the taxpayer to the EITC (married filing jointly, head of household, or surviving spouse) to one that did not qualify the taxpayer (married filing separately, or single). ${ }^{17}$ Thirty percent of the claimants were disqualified because of misreported earnings or AGI.

Incorporating compliance data into the analysis leads to the following conclusion about EITC participation: if 31.3 percent of the 12.616 million taxpayers who claimed the credit in 1990 were

\footnotetext{
${ }^{16}$ In 1987, 67.5 million exemptions were claimed for dependents.

${ }^{17}$ The categories Holtzblatt presented are not mutually exclusive. For example, 41 percent of the returns disqualified had both the child exemption disallowed and filing status changed. A taxpayer claiming the EITC that did not meet the support test could have the child exemption disallowed and their filing status changed. Similar information about the reasons for noncompliance is not available from the 1988 TCMP.
} 
ineligible, 8.659 million eligible taxpayers claimed the EITC. ${ }^{18}$ Comparing this estimate to the population of eligibles (including the support test) leads to estimated EITC participation rates of 89.7 percent with SIPP data and 86.1 percent with tax return data augmented with SIPP.

c) $\quad$ A Preferred Participation Rate Estimate

Participation rate calculations that use one data source to determine the eligible population and different sources to determine (eligible) recipients are limited. Among other problems, it is difficult to accurately determine tax filing status using household- and family-based data such as the CPS and SIPP. Scholz (1990), for example, found roughly twice as many heads of households with incomes above $\$ 10,000$ in IRS tax return data than in both the 1984 CPS and the 1984 SIPP. This discrepancy will clearly affect the participation rate calculation, in this case biasing it upward. It is also impossible to examine the characteristics of eligible nonparticipants and ineligible participants when eligibility and participation are not identified in the same data set.

The data used for this paper provide a unique opportunity to calculate participation rates. In 1990 the IRS calculated and paid the EITC to all taxpayers who appeared eligible on the basis of their tax form, regardless of whether they claimed the credit. ${ }^{19}$ Thus, the most straightforward way of calculating participation is to determine what percentage of eligible households filed tax returns. As mentioned earlier, 68.8 percent of the SIPP respondents provided validated social security numbers

\footnotetext{
${ }^{18}$ The data from the 1988 TCMP, summarized in Table 2, show that 31.3 percent of the 1988 EITC claims were inappropriate. The 1988 data are comparable to tax year 1990 because the same basic statutory provisions applied in both years.

${ }^{19}$ The U.S. General Accounting Office (1992b) reports that in 1991, ". . . if the taxpayer did not claim the EIC but the tax return information on filing status, dependents, and income appeared to meet the EIC qualifications, the computer would automatically calculate the EIC. A tax examiner would then review the return to determine if there was information that indicated the taxpayer was not entitled to the EIC." The same procedures applied in 1990.
} 
that were linked directly to tax returns. ${ }^{20}$ Another 9.2 percent of the sample were not matched, but they reported in the tax topical module that they filed returns; altogether, therefore, 78.0 percent of the sample filed tax returns. ${ }^{21}$ Another 18.3 percent of the sample did not file a return--that is, they provided a validated social security number and were not matched to a tax return, or they did not have a validated social security number but reported on the tax topical module that they did not file. The remaining 3.7 percent of households did not provide a valid social security number and did not respond to the tax topical module. It is impossible to determine whether these households filed.

Dropping the "unknown filers," I find that 87.6 percent of eligible households under the SIPPbased definition (with the support test) filed tax returns and hence received the EITC. The comparable figures are 85.6 percent when the support criterion is dropped and 85.2 percent under the tax-returnbased eligibility criterion. If all the unknown filers are assumed to file, the participation rate estimates are 85.8 to 88.1 percent. If all unknown filers are assumed not to file, the participation rate estimates are 81.9 to 84.2 percent. These rates, which range from 81.9 to 88.1 , are strikingly similar to the estimates reported in the previous section.

It is conceivable that EITC-eligible taxpayers are filing form 1040EZ--a form designed for single taxpayers with no dependents and wage, salary, and interest income under \$400--rather than forms that would allow the IRS to flag the return as being eligible for the credit in the event the

\footnotetext{
${ }^{20}$ It is to be expected that not all households that participated in the SIPP and filed were matched to tax returns. The structure of SIPP is such that new households are added to the survey as other households attrite. Validated social security numbers were not collected for households not in the first wave of the survey, and hence these households will not be linked to returns. In addition, households may have provided valid social security numbers, but if the marital status of the household did not conform to the filing status of the return, the tax return match was not made.

${ }^{21}$ I thank George Yin for pointing out the following back-of-envelope calculation that suggests the filing rate is plausible. Graeber, Nichols, and Sparrow (1992) estimate a total nonfiling population for 1988 of 100 million persons, but this estimate includes, for example, children with social security numbers. If we assume the 100 million includes all of the estimated 60 million children in the United States in 1988, there were 40 million individual nonfilers out of an adult population of about 180 million, a filing rate of 78 percent.
} 
taxpayer did not claim it. Because a taxpayer cannot claim a dependency exemption on the 1040EZ, filing such a return would mean that an eligible taxpayer would not receive the credit. In practice, using the two SIPP-based definitions of EITC eligibility, 170,000 to 190,000 eligible taxpayers file returns using the 1040EZ. Taking account of this group changes the participation rate estimates to 80.1 percent to 86.3 percent, depending on the treatment of the support test, definition of eligibility, and whether or not unknown filers are assumed to file returns. These participation rate estimates are my preferred estimates; they imply that 1.3 million (13.7 percent) to 2.1 million (19.9 percent) taxpayers eligible for the credit fail to receive it.

\section{d) The SIPP Tax Topical Module}

An alternative method of calculating EITC participation would be to rely on the specific EITC recipiency question asked in the SIPP tax topical module. This question is of limited value, however, because 53 percent of the households in the survey did not respond to it. ${ }^{22}$ Surprisingly, if the sample is restricted to those who did answer the recipiency question, roughly 50 percent of EITCeligible households (2.8 million households) reported that they did not receive the credit. This raised concerns about the accuracy of their reports. A possible explanation for this is that over 40 percent of EITC recipients used paid tax preparers, so it seems possible that taxpayers might not be aware or remember that they took the credit, even when in fact they did. ${ }^{23}$ To examine this possibility, I restricted the sample further to those who reported in the topical module that they referred to their tax return when answering the questions, as I expect the responses of this population to be more accurate than those of the general population. Out of the roughly 49.5 million households represented by the

\footnotetext{
${ }^{22}$ Most of these households were not asked the questions during the SIPP interview. Apparently if the interviews were taking too long or the interviewer felt that asking the questions might jeopardize the respondent's subsequent cooperation in the panel survey, the topical module questions were skipped.

${ }^{23}$ I thank Janet Holtzblatt of the U.S. Treasury Department for pointing this out to me.
} 
weighted responses to the EITC recipiency question, only 20 percent referred to tax documents during the interview. Nevertheless, restricting the sample to these households is revealing. Seventy-five percent of the eligible households under the SIPP-based definition stated they received the credit, and 80 percent of those eligible under the tax-return-based definition stated they received the credit. Therefore, although the topical module questions lead to a slightly lower estimate of EITC participation, they are generally consistent with the estimates based on the other approaches that consider the full population.

Piecing together data from different sources yields participation rate estimates between 86.1 and 89.7 percent; using the exact match data yields estimates between 80.1 and 86.3 percent; and using the tax topical module responses for a smaller, and possibly atypical, population yields estimates between 75 and 80 percent. ${ }^{24}$ All these estimates are considerably higher than participation rates in other programs directed toward the low-income population. Haveman (1987, pp. 87-88), for example, reported that food stamp and SSI participation rates were 50 to 60 percent in the late 1970 s, whereas AFDC participation varied from 95 percent (in the District of Columbia) to 56 percent (in Arizona) in 1975-76. Blank and Ruggles (1993) calculate AFDC participation rates of 62 to 72 percent and food stamp participation rates of 54 to 66 percent, using data from the 1986 and 1987 panels of the SIPP.

A number of factors presumably contribute to the high EITC participation rate. There is little or no stigma associated with the EITC, while stigma associated with transfer programs such as AFDC and food stamps may discourage participation in those programs (Moffitt, 1983). In addition, transfer program recipients are perhaps less likely to know about or take advantage of programs they may be eligible for: they are, on average, less educated and less attached to the labor market than EITC-

\footnotetext{
${ }^{24}$ The participation rate in 1990 is almost certain to be higher than the 1984 rate because higherincome households are eligible for the credit: the maximum income that qualified for the credit in 1984 was $\$ 12,579$ (in 1990 dollars) while in 1990 it was $\$ 20,264$, and higher-income households are more likely to file tax returns. In addition, there has been a considerable amount of EITC outreach effort since 1984.
} 
eligible taxpayers, who must work to receive the credit. While EITC participation is high relative to transfer program participation, rates of EITC noncompliance are also high. As shown in Table 2, 31 percent of EITC claimants in 1988 were ineligible, while Holtzblatt (1991) reports that overpayment error rates were 6.1 percent for AFDC and 8.3 percent for food stamps in 1985.

Changes to the credit in OBRA90 are likely to affect estimates of both the participation rate and noncompliance. The OBRA90 reforms added a two-page form (Schedule EIC), the first page of which must now be completed before the IRS will compute the credit and make an award. Otherwise, if the taxpayer appears to be eligible but fails to claim the credit, the IRS will send notification that encourages them to file an amended return (Yin and Forman, 1993, p. 953). ${ }^{25}$ The EITC participation rate will fall if eligible taxpayers who fail to claim the credit do not respond to the IRS notification that encourages them to file an amended return. The additional schedule and simplification of the rules defining a qualifying child presumably reduced noncompliance, though there is no empirical evidence on this issue. ${ }^{26}$

\footnotetext{
${ }^{25}$ According to unpublished figures from Sharon Patton at the Returns Processing Division of the IRS, as of June 5, 1993, the IRS had mailed 832,000 EITC notices to potentially eligible taxpayers for the 1992 tax year. The IRS computed and awarded the credit to 597,000 taxpayers in 1990. My estimates indicate that somewhat more than 8.1 million taxpayers received the credit in 1990, which implies, if the IRS figures are accurate, a high degree of EITC awareness among the low-income taxpaying population.

${ }^{26}$ Recall that in 1990 the rules defining a qualified child changed from providing more than half the support for a child to a requirement that the child has to live with the claimant for more than half the year (see note 5). This change presumably eliminated one substantial source of error. Anecdotal evidence from the IRS indicates that the error rate of EITC claims has fallen substantially.
} 


\section{CHARACTERISTICS OF ELIGIBLE NONPARTICIPANTS AND INELIGIBLE PARTICIPANTS}

In this section I estimate a Probit regression to examine the characteristics of eligible households that do not receive the EITC. Because until recently no single data set existed that would have enabled one to determine both eligibility and participation, no previous study has examined characteristics correlated with "eligible-nonparticipation." Doing so should help increase the effectiveness of EITC outreach efforts (see note 4) and provide insight into why some eligible households fail to claim the credit. Given the importance of noncompliance when analyzing the EITC, I also use the tax topical module questions about EITC participation to analyze the characteristics of ineligible households that claim the credit. $^{27}$

There are a number of reasons for which eligible taxpayers may not file tax returns to receive the EITC. A taxpayer who has illegally failed to file in previous years or has cheated on previous returns may rationally choose not to enter the IRS system. It is very difficult, given available data, to find variables that proxy for previous noncompliance. In the regression model of EITC participation I include the amount of self-employment income and self-employment income as a percentage of total earnings because there are fewer information-matching requirements for self-employment income, which allows taxpayers greater discretion over reporting such income. At the same time, I expect those with more wage income or who work more hours to be more likely to file for the credit. For the latter effect I include the number of weeks worked full-time, part-time, and weeks unemployed, as well as average hours worked in a typical week.

\footnotetext{
${ }^{27}$ This portion of the analysis is more speculative than the rest of the paper, owing to data limitations. Ineligible participants are identified as taxpayers who claimed on the tax topical module that they took the EITC, referred to tax documents when responding to the tax topical module, and were not eligible for the credit (the analysis is done with both the SIPP-based and the tax-returndefinition of eligibility). If people, even with tax documents, did not accurately respond to the EITC topical module question, my results will not be accurate.
} 
Taxpayers may also view the inconvenience of filing a return as being greater than the potential EITC benefit. Eligible nonfilers are not necessarily breaking the law since they may have no income tax liability. For example, married couples who would have filed a joint return with incomes below $\$ 10,600$ in 1992 were not required to file. If such a couple had two children and an income of $\$ 10,600$, they would have been entitled to an EITC of $\$ 1,384$ in 1992 . I expect that the larger the potential EITC payment, the more likely the taxpayer will participate. I also include dummy variables for whether the taxpayer lives in a state without a state income tax, with the expectation that taxpayers are more likely to file a federal return if they also need to file a state return, ${ }^{28}$ and for whether the taxpayer lives in a state with a state-level EITC, with the expectation that taxpayers are more likely to file a federal return to receive the EITC if they can also file a state return to possibly get an additional credit. $^{29}$

EITC outreach efforts are predicated on the belief that low-income taxpayers are not aware of the credit and hence are less likely to file for it. I include a broad range of economic and demographic characteristics to proxy for this lack of information. These include public assistance income, age, family size, pension income, social security income, educational attainment dummies (no high school diploma is the omitted category), urbanization (in central city, out of central city, in nonmetropolitan area), and dummy variables for whether the taxpayer is married, female, black, of Spanish origin, received food stamps, and is a homeowner. Because at least some outreach has been targeted toward transfer program caseworkers, transfer recipients may have different EITC participation

\footnotetext{
${ }^{28}$ States that do not tax wages include Alaska, Connecticut, Florida, Nevada, New Hampshire, Tennessee, Texas, and Washington. Two additional states that should be included, South Dakota and Wyoming, are aggregated with more than one other state in the data and hence were not included as ones in the dummy variable.

${ }^{29}$ Wisconsin, Maryland, Rhode Island, Vermont, and Iowa had state EITCs in 1990 (Minnesota added one in 1991). Vermont is aggregated with Maine in the data, Iowa is aggregated with South and North Dakota. All these states are included as ones in the state EITC dummy variable.
} 
patterns than other households. Finally, I include 13 occupational dummy variables and dummy variables for households living in the nine largest states in the sample. Descriptive statistics for the participation rate sample are given in Appendix Table 1.

The dependent variable in the Probit regression in Table 3 takes the value 1 if the taxpayer was eligible for the EITC but did not file a tax return. ${ }^{30}$ The coefficients indicate that higher-income taxpayers--whether income is from wages, pensions, or self employment--are more likely to receive the credit, as are those who are in the labor force, even if they are temporarily unemployed (although the t-statistics of the pension and employment variables show they are not significant at the usual levels). As expected, the greater the percentage of earnings consisting of self-employment income, the less likely the taxpayer is to file a return.

The transactions costs variables also are generally significant in the expected direction. Not surprisingly, the larger the potential EITC payment, the more likely the taxpayer is to file. EITCeligible taxpayers residing in states without state income taxes are less likely to file a federal return. The state EITC variable is insignificantly different from zero.

A large number of taxpayer characteristics are significantly correlated with nonparticipation. These include receiving income from public assistance (AFDC and general assistance), having a larger family, being unmarried, being male, and being of Spanish origin. Surprisingly, once a variety of income sources, labor market status, and demographic variables are controlled for, nonparticipation increases with education so that taxpayers with college degrees are the least likely to participate relative to those without high school diplomas. Among the occupational categories, those working in such private-household occupations as launderers, cooks, housekeepers, and child care workers are significantly less likely to receive the credit than those whose occupations are not reported (the

\footnotetext{
${ }^{30}$ Tables 3 and 4 use the eligibility definition that is entirely SIPP-based. Results using the definition that incorporates tax return data for those households that were matched to returns are similar and are available from the author on request.
} 
TABLE 3

Characteristics of Eligible Households that Did Not Receive the EITC: Probit Regression (1=eligible nonparticipant, $0=$ =eligible participant $)$

\begin{tabular}{|c|c|c|c|}
\hline & Coefficient & Standard Error & T-statistic \\
\hline Constant & -.895 & .374 & 2.395 \\
\hline Social Security & $2.84 \mathrm{e}-05$ & $1.81 \mathrm{e}-05$ & 1.563 \\
\hline Public Assistance & $1.10 \mathrm{e}-04$ & $4.26 \mathrm{e}-05$ & 2.588 \\
\hline Wage Income & $-4.73 e-05$ & $1.21 \mathrm{e}-05$ & 3.895 \\
\hline Property Income & $4.25 \mathrm{e}-06$ & $4.06 \mathrm{e}-05$ & 0.105 \\
\hline Pension Income & $-6.88 \mathrm{e}-05$ & $4.47 \mathrm{e}-05$ & 1.539 \\
\hline Self-Employment Income & $-9.03 e-05$ & $2.45 \mathrm{e}-05$ & 3.683 \\
\hline SE Income/Earned Income & .013 & .003 & 4.496 \\
\hline Age & -.006 & .004 & 1.507 \\
\hline Weeks Full-time & -.006 & .004 & 1.336 \\
\hline Weeks Part-time & -.005 & .005 & 1.206 \\
\hline Weeks Unemployed & -.006 & .005 & 1.094 \\
\hline Average Hours & $-8.04 \mathrm{e}-4$ & .004 & 0.198 \\
\hline Family Size & .088 & .030 & 2.895 \\
\hline Food Stamps (y/n) & .019 & .095 & 0.201 \\
\hline Married & -.344 & .160 & 2.152 \\
\hline Female & -.451 & .162 & 2.784 \\
\hline Black & .131 & .095 & 1.376 \\
\hline Spanish Origin & .351 & .103 & 3.396 \\
\hline Homeowner & -.070 & .083 & 0.844 \\
\hline Central City & .241 & .197 & 1.226 \\
\hline Outside Central City & .219 & .197 & 1.113 \\
\hline Nonmetro Areas & .113 & .203 & 0.558 \\
\hline High School Graduate & .050 & .094 & 0.529 \\
\hline Some College & .237 & .121 & 1.962 \\
\hline College Graduate & .357 & .168 & 2.125 \\
\hline EITC & $\begin{array}{r}-4.76 \mathrm{e}-04 \\
\quad \text { (table co }\end{array}$ & $1.40 \mathrm{e}-4$ & 3.401 \\
\hline
\end{tabular}


TABLE 3, continued

\begin{tabular}{|c|c|c|c|}
\hline & Coefficient & Standard Error & T-statistic \\
\hline No state income tax $(0,1)$ & .481 & .161 & 2.988 \\
\hline State EITC & .126 & .177 & 0.710 \\
\hline Executive, Manager, Administrator & .494 & .297 & 1.667 \\
\hline Professional Specialty & .502 & .302 & 1.661 \\
\hline Technicians, Related Support & .393 & .435 & 0.903 \\
\hline Sales & .554 & .282 & 1.966 \\
\hline Administrative Support, Clerical & .402 & .277 & 1.455 \\
\hline Private Household & 1.93 & .375 & 5.139 \\
\hline Protective Service & .238 & .443 & 0.537 \\
\hline Other Service & .448 & .266 & 1.683 \\
\hline Farming, Forestry, Fishing & .072 & .323 & 0.224 \\
\hline Precision Product, Craft, Repair & .548 & .264 & 2.075 \\
\hline Machinists, Assembly, Inspect & .129 & .286 & 0.449 \\
\hline Transport, Material Moving & .685 & .279 & 2.452 \\
\hline $\begin{array}{l}\text { Handlers, Equipment, Cleaners, } \\
\text { Laborers }\end{array}$ & .815 & .273 & 2.981 \\
\hline California & .270 & .132 & 2.041 \\
\hline New York & .257 & .162 & 1.587 \\
\hline Texas & -.661 & .199 & 3.324 \\
\hline Pennsylvania & .085 & .221 & 0.383 \\
\hline Illinois & .432 & .178 & 2.428 \\
\hline Ohio & .376 & .190 & 1.978 \\
\hline Florida & -.292 & .209 & 1.398 \\
\hline Michigan & -.415 & .323 & 1.284 \\
\hline New Jersey & .330 & .211 & 1.563 \\
\hline \multicolumn{4}{|l|}{ Obs $=2,236$} \\
\hline \multicolumn{4}{|l|}{ Likelihood $=-716.17$} \\
\hline Pseudo $\mathrm{R}^{2}=.1643$ & & & \\
\hline
\end{tabular}

Source: 1990 Survey of Income and Program Participation. 
omitted category). Other occupations that are significantly correlated with nonparticipation are sales; precision production, craft, and repair (which includes mechanics and construction); transportation and material moving; and handlers, equipment cleaners, helpers, and laborers. Three state dummies, California, Illinois, and Ohio, are positive and significant. Taxpayers in Texas appear to have high rates of participation, but the magnitude of the coefficient is offset by the no-state-tax dummy, which also applies to Texas. In separate regressions that include industry rather than occupational dummies (not reported), by far the largest effect was in private household services, while taxpayers in mining, construction, and forestry and fisheries were also significantly less likely to participate when eligible.

The coefficient estimates and significance of the self-employment-to-earned-income ratio, the EITC variable, the educational dummies, the state income tax dummy, and the household services occupational and industry dummies are consistent with voluntary or rational reasons for nonparticipation. That is, the benefit of the EITC may not be worth more than the costs of preparing a tax return when the taxpayer is entitled to a smaller credit, when the reporting of self-employment income may cause scrutiny of previous returns, and when the taxpayer does not also need to prepare a state return. Workers in household services may choose not to file tax returns because of complications involved with the social security payroll tax. It would seem unlikely that informational barriers are the primary explanation of nonparticipation when college-educated taxpayers are significantly less likely to receive the credit than taxpayers with lower educational attainment, though with the methodology used here it is impossible to tell whether voluntary reasons characterize the dominant share of total nonparticipation.

Table 4 shows the results of a similar analysis focusing on taxpayers who inappropriately claim the EITC. ${ }^{31}$ The sample is restricted to households in the tax topical module that answered the EITC recipiency question either "yes" or "no" and referred to tax documents when providing

\footnotetext{
${ }^{31}$ Descriptive statistics for the sample used for Table 4 are given in Appendix Table 2.
} 
TABLE 4

\section{Characteristics of Ineligible Households that Received the EITC: Probit Regression (1=ineligible participant, $0=$ =ligible participant or ineligible nonparticipant)}

\begin{tabular}{|c|c|c|c|}
\hline & Coefficient & Standard Error & T-statistic \\
\hline Constant & -1.43 & .391 & 3.655 \\
\hline Social Security & $-1.71 \mathrm{e}-05$ & $2.23 e-05$ & 0.767 \\
\hline Public Assistance & $1.95 \mathrm{e}-04$ & $6.45 \mathrm{e}-05$ & 3.023 \\
\hline Wage Income & $-1.04 \mathrm{e}-05$ & $4.62 \mathrm{e}-06$ & 2.248 \\
\hline Property Income & $-3.64 \mathrm{e}-05$ & $2.22 \mathrm{e}-05$ & 1.641 \\
\hline Pension Income & $-2.65 e-05$ & $2.39 \mathrm{e}-05$ & 1.110 \\
\hline Self-Employment Income & $6.50 \mathrm{e}-06$ & $3.54 \mathrm{e}-06$ & 1.836 \\
\hline SE Income/Earned Income & .002 & .002 & 0.846 \\
\hline Age & .001 & .005 & 0.292 \\
\hline Weeks Full-time & $-6.16 e-04$ & .005 & 0.120 \\
\hline Weeks Part-time & $-8.71 \mathrm{e}-04$ & .005 & 0.167 \\
\hline Weeks Unemployed & $-6.87 e-03$ & .010 & 0.717 \\
\hline Average Hours & $1.73 \mathrm{e}-03$ & .004 & 0.394 \\
\hline Family Size & .104 & .042 & 2.463 \\
\hline Food Stamps (y/n) & .012 & .164 & 0.073 \\
\hline Married & .058 & .185 & 0.311 \\
\hline Female & -.067 & .161 & 0.417 \\
\hline Black & .253 & .177 & 1.428 \\
\hline Spanish Origin & .123 & .148 & 0.832 \\
\hline Homeowner & .064 & .115 & 0.561 \\
\hline Central City & -.405 & .230 & 1.764 \\
\hline Outside Central City & -.267 & .228 & 1.171 \\
\hline Nonmetro Areas & -.489 & .238 & 2.050 \\
\hline High School Graduate & .134 & .144 & 0.927 \\
\hline Some College & .081 & .166 & 0.490 \\
\hline College Graduate & -.336 & .200 & 1.685 \\
\hline No state income tax $(0,1)$ & .161 & .118 & 1.359 \\
\hline State EITC & .210 & .154 & 1.360 \\
\hline \multicolumn{4}{|l|}{ Obs $=1,664$} \\
\hline \multicolumn{4}{|l|}{ Likelihood $=-413.24$} \\
\hline Pseudo $\mathrm{R}^{2}=.1039$ & & & \\
\hline
\end{tabular}

Source: 1990 Survey of Income and Program Participation. The sample is those who responded yes or no to the EITC tax topical module question and referred to tax documents when responding to the module questions. 
responses. The dependent variable in the Probit regressions takes a value of 1 if the taxpayers stated that they claimed the EITC but were not eligible by my calculations. Eligibility in Table 4 uses the SIPP-based definition, but only those results that are robust across the SIPP-based and tax-return-based eligibility definitions are discussed. I do not have strong prior expectations about the factors that will be correlated with noncompliance, other than the expectation that it is more difficult to receive the credit inappropriately when income is received in the form of wages or from other sources that have strong information-matching procedures. Because the number of inappropriate filers is quite small after making the sample selection rules (140 for the SIPP-based eligibility definition, 95 for the other) I drop the state and occupation dummies.

As expected, wage income is negatively correlated, and self-employment income is positively correlated, with inappropriate receipt of the credit. Family size is positively and significantly correlated with inappropriate claims. Taxpayers who live in nonmetropolitan areas or in central cities are less likely than those whose residential location was not available (the excluded category) to file inappropriate claims, and taxpayers with college degrees are less likely to incorrectly claim the EITC than are those without high school diplomas (the excluded category). (The coefficients on "College Grad" and "Central City" are significant at only the 10 percent level, however.) The negative and significant coefficient on wage income, while hardly definitive evidence, suggests that taxpayers who claim the EITC but are not eligible for it tend to live in low-income households. Learning more about households that inappropriately claim the EITC, perhaps as part of the TCMP process, would be useful to the extent that there is a tradeoff between raising participation among eligible households and eliminating payments to ineligible households. 


\section{ANTIPOVERTY EFFECTIVENESS AND WORK INCENTIVES OF THE EITC}

Before the August 1993 budget legislation (OBRA93) was passed, the EITC subsidy was scheduled to reach 23 percent in 1994 for taxpayers with one child and 25 percent for taxpayers with two or more children who have earned income of less than $\$ 7,990$. A taxpayer with one (two or more) child(ren) would have received the maximum credit of $\$ 1,838(\$ 1,998)$ when earned income was between $\$ 7,990$ and $\$ 12,680$. The credit was to have been phased out at a 16.43 (17.86) percent rate for earned income above $\$ 12,680$. Taxpayers would have no longer qualified for the credit when either AGI or earned income exceeded $\$ 23,760$.

OBRA93 substantially increased the EITC, eliminated the supplemental "wee tots" credit (for children less than a year old), and eliminated the credit for the purchase of health insurance for an uninsured child (see Table 1). In 1994 it will add a 7.65 percent credit for childless taxpayers between the ages of 25 and 65 who have earnings below $\$ 4,000$. The credit will be phased out at a 7.65 percent rate at incomes between $\$ 5,000$ and $\$ 9,000$. The changes for families with children will be phased in, as follows. In 1995 the credit for taxpayers with one child will increase to 34.0 percent, but the income at which the maximum credit is earned will decrease to $\$ 6,000$ from $\$ 7,990$. Thus the maximum credit for a one-child taxpayer will increase only slightly, to $\$ 2,040$ from $\$ 1,838$. The credit will be phased out at a 15.98 percent rate for taxpayers with one child and incomes between $\$ 11,000$ and $\$ 23,760$. By 1996 the credit will be 40.0 percent for taxpayers with two or more children and incomes below $\$ 8,425$. Thus, for larger families the maximum credit will increase to $\$ 3,370$ from $\$ 1,998$. The credit will be phased out at a 21.06 percent rate for taxpayers with two or more children and incomes between $\$ 11,000$ and $\$ 27,000$. These changes are summarized in Table 1 .

Table 5 presents evidence on the "target efficiency" of the EITC prior to, and the changed EITC resulting from, OBRA93. Under both policies more taxpayers with incomes above the poverty 
TABLE 5

\section{Antipoverty Effectiveness of the EITC under the Law Prior to OBRA93 and under OBRA93 When Fully Phased in by 1996 $^{\mathrm{a}}$}

\begin{tabular}{lrr}
\hline & Prior Law & \\
& & OBRA93 $^{\mathrm{b}}$ \\
\hline $\begin{array}{l}\text { EITC-eligible taxpayers with incomes above the poverty line } \\
\text { (millions) }\end{array}$ & 6.211 & 7.582 \\
$\quad$ EITC payments to these households (millions \$) & $\$ 6,224$ & $\$ 8,994$ \\
& & \\
EITC-eligible taxpayers with incomes below the poverty line & & 5.451 \\
(millions) & $\$ 5,820$ & $\$ 9,020$ \\
$\quad$ EITC payments to these households (millions $\$$ ) & $\$ 20,156$ & $\$ 23,982$ \\
$\quad$ Pre-EITC poverty gap & \\
$\quad$ Post-EITC poverty gap & $\$ 14,544$ & $\$ 17,574$ \\
$\quad$ Number of households taken out of poverty by the EITC & 0.909 & 1.380 \\
\hline
\end{tabular}

Source: 1990 Survey of Income and Program Participation.

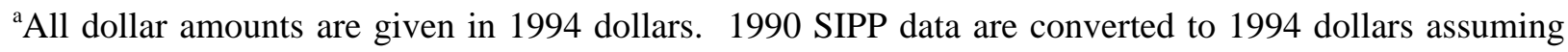
a 3 percent rate of inflation.

${ }^{b}$ Prior law calls for a 23 (25) percent EITC subsidy for one (two) children households with earned income under $\$ 7,990$ in 1994 . The credit is the maximum amount for earned income between $\$ 7,990$ and $\$ 12,680$. The credit is phased out at a rate of $16.43(17.86)$ percent for incomes between $\$ 12,680$ and $\$ 23,760$.

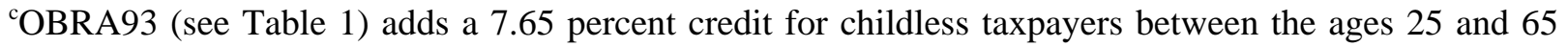
with earned income below $\$ 4,000$, a 34.0 percent credit for one-child taxpayers with earned income below $\$ 6,000$, and a 40.0 percent credit for taxpayers with two or more children with earned income below $\$ 8,425$. The flat range of the schedule stops at $\$ 5,000$ for childless taxpayers and $\$ 11,000$ for taxpayers with one or more children. The phase-out rates are 7.65 percent, 15.98 percent, and 21.06 percent, so the credit is fully phased out at $\$ 9,000, \$ 23,760$, and $\$ 27,000$.

${ }^{\mathrm{d}}$ The poverty gap is defined as the difference between cash income (the sum of earnings, dividends, interest, social security, public assistance, SSI, veterans payments, pensions, unemployment, and alimony) and the poverty line. 
line than below the poverty line are eligible to receive EITC payments, but because of the progressive benefit structure of the EITC, roughly half the credit payments go to households with incomes below the poverty line. The new law increases substantially the credit payments going to taxpayers with incomes above the poverty line, primarily as a consequence of extending the break-even level of income to $\$ 27,000$ from $\$ 23,760$ for taxpayers with two or more children. The proposal increases by over 33 percent the number of taxpayers with incomes below the poverty line who will be eligible for the EITC, primarily as a consequence of extending the credit to low-income, childless taxpayers between the ages of 25 and 65 . Under current law roughly $\$ 5.6$ billion of total EITC payments help close the "poverty gap"--the difference between total cash income and the poverty line. ${ }^{32}$ Under the new law $\$ 6.4$ billion of EITC payments close the poverty gap. However, because the new law sharply increases overall expenditures on the credit, one measure of target efficiency--the fraction of total EITC payments that directly reduce the poverty gap--falls to 36 percent from 47 percent.

The target efficiency of the new legislation would be increased if the rate at which the credit was phased out was increased. However, increasing the phase-out rate would exacerbate concerns about the possible negative consequences the EITC might have on labor supply (see, for example, Hoffman and Seidman, 1990, Chapter 3, and Kosters, 1993). The EITC has different labor supply effects depending on whether the taxpayer's income is in the subsidy, flat, or phase-out range of the credit. The subsidy range of the credit works as a wage subsidy, increasing the worker's marginal return to labor. For taxpayers with no earned income, the substitution effect associated with higher wages will provide an unambiguous incentive to increase labor supply. For taxpayers with incomes in the subsidy range, the substitution effect will increase labor supply, whereas the income effect will

\footnotetext{
${ }^{32}$ This reduction in the poverty gap will not be reflected in official government statistics as the EITC is not included in the pretax, posttransfer income concept used to measure poverty.
} 
decrease labor supply. ${ }^{33}$ The net effect is ambiguous. There is only an income effect in the flat range of the credit, which provides an unambiguous incentive to reduce labor supply. In the phase-out range, the substitution and income effects work in the same direction to decrease labor supply. These effects prompt the concern that if a disproportionate fraction of the EITC population is in the flat and phase-out ranges of the credit, increases in the EITC could lead to a net reduction in the labor supplied by low-income workers.

Table 6 shows that OBRA93 increases by 42 percent the number of EITC recipients who are in the subsidy range of the credit, primarily by extending the credit to taxpayers between the ages of 25 and 65 without children. At the same time, the new changes almost double payments to households with incomes in the phase-out range of the credit. There is little empirical evidence concerning the behavioral effects of simultaneously increasing tax credits and raising marginal tax rates on relatively low wage workers. Determining these behavioral responses is a critical component in providing a complete evaluation of the new EITC changes.

\section{CONCLUSIONS}

This paper examines several aspects of the earned income tax credit. Using three different approaches I estimate that the EITC participation rate was 75 to 90 percent in 1990, with most (and the preferred) estimates falling in the 80 to 86 percent range. These participation rates imply that fewer than 2.1 million taxpayers entitled to the credit failed to receive it. Several of the characteristics correlated with nonparticipation by eligibles are consistent with rational or voluntary

\footnotetext{
${ }^{33}$ Economists find it useful to decompose price changes into two effects. A wage subsidy increases the return to labor, making leisure more expensive. Heuristically, the substitution effect suggests that with leisure more costly, people take less (work more) as long as leisure is a normal good. The income effect suggests that with a higher wage rate people have more income for given hours of work. With higher income, people buy more of everything they like including leisure, which implies they will work less.
} 
TABLE 6

Labor Market Incentives of the EITC, as Indicated by Payment Levels in Relation to Income ${ }^{\text {a }}$

\begin{tabular}{lrr}
\hline & Prior Law & OBRA93 $^{\mathrm{b}}$ \\
\hline Number of taxpayers in EITC subsidy range (millions) & 2.116 & 3.005 \\
EITC payments to these households (millions \$) & $\$ 2,275$ & $\$ 3,161$ \\
& & 2.055 \\
Number of taxpayers in flat range (millions) & 2.223 & $\$ 4,382$ \\
EITC payments to these households (millions \$) & $\$ 4,269$ & 7.972 \\
Number of taxpayers in phase-out range (millions) & 5.955 & $\$ 10,469$ \\
EITC payments to these households (millions \$) & $\$ 5,500$ & \\
\hline
\end{tabular}

Source: 1990 Survey of Income and Program Participation.

${ }^{a}$ As described in the text, income and substitution effects work in opposing directions for taxpayers in the subsidy range of the credit. For taxpayers in the flat range or phase-out range of the EITC schedule, there is an unambiguous incentive to reduce labor market hours.

bPrior law calls for a 23 (25) percent EITC subsidy for one (two) child households with earned income under $\$ 7,990$ in 1994 . The credit is the maximum amount for earned income between $\$ 7,990$ and $\$ 12,680$. The credit is phased out at a rate of 16.43 (17.86) percent for incomes between $\$ 12,680$ and $\$ 23,760$.

${ }^{c}$ For 1996 and beyond (see Table 1), OBRA93 adds a 7.65 percent credit for childless taxpayers between the ages of 25 and 65 with earned income below $\$ 4,000$, a 34.0 percent credit for one-child taxpayers with earned income below $\$ 6,000$, and a 40.0 percent credit for taxpayers with two or more children with earned income below $\$ 8,425$. The flat range of the schedule stops at $\$ 5,000$ for childless taxpayers and $\$ 11,000$ for taxpayers with one or more children. The phase-out rates are 7.65 percent, 15.98 percent, and 21.06 percent, so the credit is fully phased out at $\$ 9,000, \$ 23,760$, and $\$ 27,000$. 
explanations. In particular, taxpayers less likely to file when eligible are those who are entitled to a smaller EITC, have a greater share of earnings composed of self-employment income, live in states without state income taxes, work in household service occupations, and have higher levels of education.

In 1988 a large proportion of EITC recipients were not eligible for the credit. In the absence of more detailed summary information from the TCMP audits, it is difficult to provide details on the characteristics of households that inappropriately claimed the EITC. My evidence suggests that noncompliance was negatively correlated with wage and salary income and positively correlated with self-employment income. Legislative changes in 1990 probably reduced noncompliance, but with the significant expansion of the credit in OBRA93 the incentive to file false claims will increase. Additional information on EITC compliance will be valuable.

I also show that more than half the EITC recipients under the law prior to OBRA93 and under the new law are in the phase-out range of the credit, where both the income and substitution effects discourage labor supply. For households not working or in the subsidy range of the credit, the EITC may increase labor supply by increasing the return to work. However, more needs to be known about the other tax rates these households face through direct taxation--the payroll tax, sales and excise taxes, state and local income taxes, and property taxes--and through indirect taxes such as those imposed through the transfer system. ${ }^{34}$ To the extent these marginal tax rates are high, the presumed beneficial labor supply incentives of the EITC may be overcome by the layering of other marginal tax rates for lower-income workers.

The EITC plays a central role in public policy as it affects the working poor. By the time the OBRA93 EITC changes are fully phased in, the credit will deliver benefits to more than six million

\footnotetext{
${ }^{34}$ See Chernick and Reschovsky (1990) for a nice discussion of the explicit tax rates (caused by the property tax, sales tax, and state and federal income tax) faced by the poor in several states.
} 
working taxpayers with incomes below the poverty line, will close the poverty gap by $\$ 6.4$ billion, and will raise the incomes of over one million taxpayers to a level above the poverty line. 
APPENDIX TABLE 1

Descriptive Statistics for EITC-Eligible Taxpayers (Sample in Table 3)

\begin{tabular}{|c|c|c|c|c|}
\hline & Mean & $\begin{array}{l}\text { Standard } \\
\text { Deviation }\end{array}$ & $\begin{array}{l}\text { Minimum } \\
\text { Amount } \\
\text { Reported }\end{array}$ & $\begin{array}{l}\text { Maximum } \\
\text { Amount } \\
\text { Reported }\end{array}$ \\
\hline Nonparticipation & .128 & .335 & 0 & 1 \\
\hline Social Security & $\$ 629$ & $\$ 2,308$ & $\$ 0$ & $\$ 20,000$ \\
\hline Public Assistance & $\$ 220$ & $\$ 794$ & $\$ 0$ & $\$ 8,480$ \\
\hline Wage Income & $\$ 10,808$ & $\$ 5,689$ & $\$ 0$ & $\$ 20,234$ \\
\hline Property Income & $\$ 153$ & $\$ 863$ & $\$-13,898$ & $\$ 13,957$ \\
\hline Pension Income & $\$ 159$ & $\$ 1,124$ & $\$ 0$ & $\$ 17,156$ \\
\hline Self-Employment Income & $\$ 737$ & $\$ 2,735$ & $\$ 0$ & $\$ 20,015$ \\
\hline SE Income/Earned Income & 6.72 & 22.7 & 0 & 100 \\
\hline Age & 36.4 & 11.2 & 16 & 78 \\
\hline Weeks Full-time & 34.5 & 19.7 & 0 & 52 \\
\hline Weeks Part-time & 7.2 & 13.9 & 0 & 52 \\
\hline Weeks Unemployed & 3.6 & 8.3 & 0 & 52 \\
\hline Average Hours & 37.8 & 13.3 & 0 & 99 \\
\hline Family Size & 3.6 & 1.4 & 2 & 13 \\
\hline Food Stamps (y/n) & .275 & .447 & 0 & 1 \\
\hline Married & .430 & .495 & 0 & 1 \\
\hline Female & .515 & .500 & 0 & 1 \\
\hline Black & .243 & .429 & 0 & 1 \\
\hline Spanish Origin & .206 & .405 & 0 & 1 \\
\hline Homeowner & .456 & .498 & 0 & 1 \\
\hline Central City & .373 & .484 & 0 & 1 \\
\hline Outside Central City & .335 & .472 & 0 & 1 \\
\hline Nonmetro Areas & .246 & .430 & 0 & 1 \\
\hline High School Graduate & .462 & .499 & 0 & 1 \\
\hline Some College & .164 & .370 & 0 & 1 \\
\hline College Graduate & .065 & .247 & 0 & 1 \\
\hline
\end{tabular}


APPENDIX TABLE 1, continued

\begin{tabular}{|c|c|c|c|c|}
\hline & Mean & $\begin{array}{l}\text { Standard } \\
\text { Deviation }\end{array}$ & $\begin{array}{l}\text { Minimum } \\
\text { Amount } \\
\text { Reported }\end{array}$ & $\begin{array}{l}\text { Maximum } \\
\text { Amount } \\
\text { Reported }\end{array}$ \\
\hline EITC & $\$ 578$ & $\$ 308$ & $\$ 2$ & $\$ 953$ \\
\hline No state income tax $(0,1)$ & .217 & .412 & 0 & 1 \\
\hline State EITC & .056 & .231 & 0 & 1 \\
\hline Executive, Manager, Administrator & .049 & .216 & 0 & 1 \\
\hline Professional Specialty & .043 & .204 & 0 & 1 \\
\hline Technicians, Related Support & .013 & .115 & 0 & 1 \\
\hline Sales & .087 & .282 & 0 & 1 \\
\hline Administrative Support, Clerical & .147 & .354 & 0 & 1 \\
\hline Private Household & .012 & .107 & 0 & 1 \\
\hline Protective Service & .011 & .105 & 0 & 1 \\
\hline Other Service & .189 & .391 & 0 & 1 \\
\hline Farming, Forestry, Fishing & .043 & .204 & 0 & 1 \\
\hline Precision Product, Craft, Repair & .110 & .313 & 0 & 1 \\
\hline Machinists, Assembly, Inspect & .106 & .308 & 0 & 1 \\
\hline Transport, Material Moving & .065 & .247 & 0 & 1 \\
\hline $\begin{array}{l}\text { Handlers, Equipment Cleaners, } \\
\text { Laborers }\end{array}$ & .071 & .257 & 0 & 1 \\
\hline California & .112 & .316 & 0 & 1 \\
\hline New York & .063 & .242 & 0 & 1 \\
\hline Texas & .102 & .302 & & 1 \\
\hline Pennsylvania & .034 & .181 & 0 & 1 \\
\hline Illinois & .042 & .201 & 0 & 1 \\
\hline Ohio & .037 & .188 & 0 & 1 \\
\hline Florida & .065 & .246 & 0 & 1 \\
\hline Michigan & .023 & .149 & 0 & 1 \\
\hline New Jersey & .030 & .172 & 0 & 1 \\
\hline Obs $=2,236$ & & & & \\
\hline
\end{tabular}

Source: 1990 Survey of Income and Program Participation.

Note: All income, social security, public assistance, and employment figures are for the year. 
APPENDIX TABLE 2

Descriptive Statistics for Households Responding Yes or No to the EITC Question in the Tax Topical Module and Used Tax Forms When Responding to the Questions (Sample in Table 4)

\begin{tabular}{|c|c|c|c|c|}
\hline & Mean & $\begin{array}{l}\text { Standard } \\
\text { Deviation }\end{array}$ & $\begin{array}{l}\text { Minimum } \\
\text { Amount } \\
\text { Reported }\end{array}$ & $\begin{array}{c}\text { Maximum } \\
\text { Amount } \\
\text { Reported }\end{array}$ \\
\hline Took EITC When Not Eligible & .079 & .270 & 0 & 1 \\
\hline Social Security & $\$ 1,126$ & $\$ 3,214$ & $\$ 0$ & $\$ 20,000$ \\
\hline Public Assistance & $\$ 76$ & $\$ 565$ & $\$ 0$ & $\$ 7,502$ \\
\hline Wage Income & $\$ 20,220$ & $\$ 19,567$ & $\$ 0$ & $\$ 100,000$ \\
\hline Property Income & $\$ 1,153$ & $\$ 4,047$ & $\$-33,226$ & $\$ 67,588$ \\
\hline Pension Income & $\$ 826$ & $\$ 3,675$ & $\$ 0$ & $\$ 42,228$ \\
\hline Self-Employment Income & $\$ 3,694$ & $\$ 14,333$ & $\$ 0$ & $\$ 200,000$ \\
\hline SE Income/Earned Income & 11.4 & 28.8 & 0 & 100 \\
\hline Age & 41.4 & 14.3 & 17 & 83 \\
\hline Weeks Full-time & 37.1 & 19.8 & 0 & 52 \\
\hline Weeks Part-time & 7.4 & 14.7 & 0 & 52 \\
\hline Weeks Unemployed & 1.9 & 5.8 & 0 & 52 \\
\hline Average Hours & 38.8 & 14.5 & 0 & 99 \\
\hline Family Size & 2.5 & 1.5 & 1 & 10 \\
\hline Food Stamps $(y / n)$ & .096 & .294 & 0 & 1 \\
\hline Married & .489 & .500 & 0 & 1 \\
\hline Female & .342 & .475 & 0 & 1 \\
\hline Black & .067 & .250 & 0 & 1 \\
\hline Spanish Origin & .119 & .324 & 0 & 1 \\
\hline Homeowner & .593 & .492 & 0 & 1 \\
\hline Central City & .348 & .476 & 0 & 1 \\
\hline Outside Central City & .388 & .487 & 0 & 1 \\
\hline Nonmetro Areas & .227 & .419 & 0 & 1 \\
\hline High School Graduate & .392 & .488 & 0 & 1 \\
\hline
\end{tabular}


APPENDIX TABLE 2, continued

\begin{tabular}{lcccc}
\hline & Mean & $\begin{array}{c}\text { Standard } \\
\text { Deviation }\end{array}$ & $\begin{array}{c}\text { Minimum } \\
\text { Amount } \\
\text { Reported }\end{array}$ & $\begin{array}{c}\text { Maximum } \\
\text { Amount } \\
\text { Reported }\end{array}$ \\
\hline Some College & .214 & .410 & 0 & 1 \\
College Graduate & .233 & .423 & 0 & 1 \\
No state income tax $(0,1)$ & .201 & .401 & 0 & 1 \\
State EITC & .102 & .302 & 0 & 1 \\
Obs. $=1,664$ & & & & \\
\hline
\end{tabular}

Source: 1990 Survey of Income and Program Participation.

Note: All income, social security, public assistance, and employment figures are for the year. 


\section{References}

Blank, Rebecca M. and Patricia Ruggles. 1993. "When Do Women Use AFDC and Food Stamps? The Dynamics of Eligibility Versus Participation." Mimeo, Northwestern University and the Urban Institute, Washington, D.C., June.

Chernick, Howard and Andrew Reschovsky. 1990. "The Taxation of the Poor." Journal of Human

Resources, 25: 712-735.

Congress for Working America. 1992. "Making Work Pay: The Milwaukee Earned Income Credit Campaign, 1991-1992." Milwaukee, Wisconsin.

Danziger, Sheldon H., Robert H. Haveman, and Robert D. Plotnick. 1986. "Antipoverty Policy: Effects on the Poor and the Nonpoor." In Fighting Poverty: What Works and What Doesn't, ed. Sheldon H. Danziger and Daniel H. Weinberg. Cambridge Mass.: Harvard University Press.

Ellwood, David T. 1988. Poor Support: Poverty in the American Family. New York: Basic Books.

Forman, Jonathan Barry. 1989. "Using Refundable Tax Credits to Help Low-Income Families." Loyola Law Review, 35(1): 117-142.

Gabe, Thomas. 1989. "Distributional Effects of Selected Proposals to Modify the Earned Income Tax Credit." Mimeo, Congressional Research Service, Washington, D.C., September 28.

Gabe, Thomas. 1993. "The Earned Income Tax Credit (EITC), Current Law, and the Clinton Proposal: Characteristics of Eligible Families." Mimeo, Congressional Research Service, Washington, D.C., May 25.

Graeber, Michael J., Bonnie L. Nichols, and D. Arthur Sparrow. 1992. "Characteristics of Delinquent Returns." The IRS Research Bulletin, December 1.

Greater Milwaukee Committee. 1990. "The Milwaukee Earned Income Credit Campaign: Reaching Out to the Poor." Project Report, Milwaukee, Wisconsin, July. 
Haveman, Robert H. 1987. Poverty Policy and Poverty Research: The Great Society and the Social

Sciences. Madison, Wisconsin: University of Wisconsin Press.

Haveman, Robert H. 1988. Starting Even: An Equal Opportunity Program to Combat the Nation's New

Poverty. New York: Simon and Schuster.

Hoffman, Saul D. and Laurence S. Seidman. 1990. The Earned Income Tax Credit: Antipoverty

Effectiveness and Labor Market Effects. Kalamazoo, Michigan: W. E. Upjohn Institute for

Employment Research.

Holtzblatt, Janet. 1991. "Administering Refundable Tax Credits: Lessons from the EITC Experience." $\underline{\text { NTA- }}$ TIA Proceedings, Proceedings of the Eighty-fourth Annual Conference, pp. 180-186.

Jabine, Thomas B. 1990. SIPP Quality Profile. U.S. Bureau of the Census, Washington, D.C., May.

Kosters, Marvin H. 1993. "The Earned Income Tax Credit and the Working Poor." The American

Enterprise, May/June, pp. 65-72.

Lullo, Margaret J. 1993. "Statement of Margaret J. Lullo, Deputy Assistant Commissioner (Taxpayer

Services), Internal Revenue Service, before the Subcommittee on Select Revenue Measures and

Human Resources, Committee on Ways and Means, U.S. House of Representatives." March 30.

Moffitt, Robert. 1983. "An Economic Model of Welfare Stigma." American Economic Review, 73(5):

$1023-1035$.

National Research Council. 1993. The Future of the Survey of Income and Program Participation, ed. C. F.

Citro and G. Kalton. Washington, D.C.: National Academy Press.

Roth, Jeffrey A., John T. Scholz, and Ann Dryden Witte. 1989. Taxpayer Compliance: Volume 1, An

Agenda for Research. Philadelphia, Pennsylvania: University of Pennsylvania Press.

Scholz, John Karl. 1990. "The Participation Rate of the Earned Income Tax Credit." Institute for Research on Poverty Discussion Paper no. 928-90, University of Wisconsin-Madison. 
Shapiro, Isaac and Robert Greenstein. 1993. "Making Work Pay: The Unfinished Agenda." Center on Budget and Policy Priorities, Washington, D.C., May.

Stathis, Jennie S. 1993. "Statement of Jennie S. Stathis, Director, Tax Policy and Administration Issues, General Government Division, General Accounting Office, before the Subcommittee on Select Revenue Measures and Human Resources, Committee on Ways and Means, U.S. House of Representatives." March 30, GAO/T-GGD-93-20.

Steuerle, Eugene and Paul Wilson. 1986. "The Taxation of the Poor and Lower Income Workers." In Ladders Out of Poverty: Report of the Project on the Welfare of Families, ed. Jack Meyer, Washington, D.C.: American Horizons.

Steuerle, Eugene and Paul Wilson. 1987. "The Earned Income Tax Credit." Focus, newsletter of the Institute for Research on Poverty, 10(1): 1-10.

U.S. Bureau of the Census. 1992. Statistical Abstract of the United States, 1992. 112 edition, Washington, D.C.

U.S. Department of Commerce, Bureau of Economic Analysis. 1991. Survey of Current Business. Washington, D.C., July.

U.S. General Accounting Office. 1992a. "Earned Income Tax Credit: Advance Payment Option is Not Widely Known or Understood by the Public." GAO/GGD-92-26, Washington, D.C., February. U.S. General Accounting Office. 1992b. "Tax Administration: IRS' 1992 Filing Season Was Successful but Not without Problems." GAO/GGD-92-132, Washington, D.C., September.

U.S. House of Representatives, Committee on Ways and Means. 1993. The Green Book: Background Material and Data on Programs within the Jurisdiction of the Committee on Ways and Means. Washington, D.C.: Government Printing Office, July. U.S. Internal Revenue Service. 1992a. Statistics of Income 1989: Individual Income Tax Returns. Washington, D.C. 
U.S. Internal Revenue Service. 1992b. Statistics of Income Bulletin. Washington, D.C., Spring.

Vaughan, Denton R. 1989. "Reflections on the Income Estimates from the Initial Panel of the Survey of Income and Program Participation (SIPP)." Office of Research and Statistics, Working Paper Series \#39, U.S. Department of Health and Human Services, Washington, D.C.

Wilson, William Julius. 1987. The Truly Disadvantaged: The Inner City, the Underclass, and Public Policy. Chicago: University of Chicago Press.

Yin, George K. and Jonathan Barry Forman. 1993. "Redesigning the Earned Income Tax Credit Program to Provide More Effective Assistance for the Working Poor." Tax Notes, May 17, pp. 951-960. 